\title{
SUCCESS EVALUATION OF SMALL AND MEDIUM-SIZED ENTERPRISES IN TERMS OF THEIR PARTICIPATION IN THE INTERNATIONALIZATION PROCESS
}

\author{
Lea Kubíčková, Lenka Procházková
}

\section{Introduction}

In recent years, globalization has been accelerated and intensified, which involves mutual approximation and interconnecting of the world's economies. Whole world has been connecting; therefore, globalization is a process of society integration on a worldwide level. The process of globalization can be seen as more or less spontaneous, whereas integration is a process controlled and organized from above via international and supranational institutions and authorities (if we omit the existence of so-called informal integration). However, globalization has not expanded evenly in all of the regions in the world, it emanates mainly from the most developed countries such as the USA, Japan or Western Europe. It is closely related not only to the internationalization of enterprises, but also to the supranational companies' development because removal of barriers and enhancing competition on domestic markets manifests in effort of enterprises to expand to the foreign market. Due to growing globalization and increasingly competitive environment, enterprises (especially those of small and medium-sized) have to react promptly to all changes. In terms of globalization, one global economy has originated consecutively and spontaneously. The role of foreign commerce and investments elevates, financial markets have been interconnecting, a capital has been concentrated and supranational corporations still more and more significantly influence not only the economic situation.

In professional literature, many various points of view on the globalization and internationalization process of enterprises are presented. Mainly the question of different opportunities of largesized and small and medium-sized enterprises is discussed.

Small and medium-sized enterprises (SMEs) represent an important market sector of economics. They are a motive power of business sphere, growth, innovations and competition ability. Moreover, they considerably contribute to the creation of vacancies and GDP. In the economic union of EU, SMEs plays a significant economic and political role. The reason is not only their high number but also the aspect of creating vacancies, social stability and innovation development dynamic. Thus, a great deal of attention has been paid to SMEs evolution and their economic, organizational and legislative support has been accentuated. An advantage of small and medium-sized enterprises lies especially in their ability to react to changes on the market in a rapid and flexible way. On the other hand, they often have to deal with insufficient funds and their access to foreign sources is more complicated than that of largesized enterprises.

Globalization process leads to intense internationalization of world economy whose result is principally international economic relations development and mutual dependence of countries. Competition coming from foreign countries keeps growing; to succeed in this strong competitive fight, small and mediumsized enterprises have to deal with the question of internationalization because it is one of possibilities how to face the competitive environment. 
For this reason, SMEs have been more frequently analysed in an effort to identify factors, which involve their ability to succeed in international activities. Those factors could positively influence other SMEs in their plans to participate in the foreign trade. However, not all the enterprises have equal conditions for entering the foreign market field. In some business spheres, the export of SMEs is supported, which is considerably helpful, mainly in case of enterprises with insufficient funds. Some of the other spheres facilitate access to the foreign market because of their sort of production.

\section{Small and Medium-Sized Enterprises - Advantages and Disadvantages in the Internationalization Process}

SMEs represent independent business units led by one or several entrepreneurs with a small number of employees, relatively limited funds and little annual turnover. On 6th May 2003, the European Commission approved a new definition of SMEs. In the Recommendation 2003/361/EC which entered into force on 1st January 2005, the Commission defined new threshold values for particular criteria to determine a small and medium-sized enterprise which take into consideration economic development since 1996, especially price trends and labour productivity. A number of employees, annual turnover and balance sum remained the measured criteria, but maximum limits for the turnover and total value of active capital were raised. Actual threshold values of particular criteria for defining small and medium-sized enterprises are: less than 250 employees, turnover of less than or equal to 50 million Euros and balance sum of less than or equal 43 million Euros. To be classified as SMEs, an enterprise has to fulfil so called condition of independence at the same time, which means that no other subject is allowed to own more than $25 \%$ of shares or voting right in the particular firm.

The small and medium-sized enterprises play an important role in national economies of particular countries. This fact displays, inter alia, in appearance of various economic, marketing and management theories which are concerned with problems of small and mediumsized enterprises' specifics and in recent years, there have been created brand new models focused not only on their management, but also on success evaluation of SMEs' activity on the domestic market and in the internationalization process.

There are several points of view on the importance of SMEs, for example according to [31] the importance of SMEs can be divided in two groups: the first one includes SMEs of social and the second one of economic significance. From the social point of view, the stabilization function of SMEs in society is accented because any changes, political or economic, signify for these enterprises a high risk. Another social contribution is proved by a fact that small and medium-sized enterprises represent a local capital and their relation to the regions in which they operate. The relation is in case of SMEs considerably closer in comparison to other types of enterprises. In addition to employment rising and their contribution to the particular region, SMEs also often participate in charity and other socially important activities. Furthermore, they partake in urbanization, involve characteristics of towns and villages, preserve and restore local historical architecture. The economic significance of SMEs which was emphasized by [31] in context of specific position of these business subjects, who fight the competition of large firms mainly by their flexibility and fast reactions to market changes, is often discussed in the professional literature, although there is not a long tradition of entrepreneurial activities in the segment of small and medium-sized enterprises in Europe.

Until the beginning of 1970's, most economies were characteristic by growth of large firms with centralized management structures associated with a development of theories accentuating advantages of a mass production. Since the beginning of 1970's, higher growth rate of employment in small enterprises (in comparison to the large ones) has started to manifest, thus their number has begun to quickly increase. A view on economic theories of firms has started to change and an emphasis has been put on motivation and stimulation of enterprises again. A decisive role in evaluating of small firms' importance in economy was played by a successful competition between Japan and USA on one side and Europe on the other. In the last three decades, the number of SMEs grew in comparison with large enterprises, by which small and medium-sized enterprises 
became an important market sector of the economy.

The economic and social contribution of SMEs can be therefore summarized into following fact: SMEs reduce negative consequences of structural changes, function as subcontractors of large firms, generate conditions for development and implementation of new technologies, create vacancies with low capital expenses and adapt fast to market demands and swings. They are a source of innovation and technological progress, employ almost $60 \%$ of active workers, contribute to an output and value added with more than a half of the whole amount, fill border market areas which are not interesting for larger firms, decentralize business activities and by this way help faster development of regions, smaller towns and villages. Furthermore, it can be emphasized that SMEs inhibit monopolistic tendencies in particular economies and accommodate to the customers' requests on local markets which big enterprises are not willing to fulfil. In addition, SMEs introduce small innovations, changes, ideas and adaptations to new customers' needs and they employ redundant workers from large firms.

During their existence, small and mediumsized enterprises have to deal with a number of disadvantages: e.g. [20] count among the most difficult ones high vulnerability to SMEs's surroundings, secondary insolvency which threaten SMEs much more seriously than bigger firms, and an absence of experts that affects most of small enterprises. Insufficient bonding capacity is a disadvantage which is also often mentioned as well as more complicated access to financing because SMEs represent more hazardous and unattractive segment for banks. The more complicated access (in comparison with bigger enterprises) to borrowed capital consequently manifests in inability to participate in business requiring large investment and their position in public tenders for government contracts is not so strong. The question of financing is related to limited financial resources for employee salaries. In addition, SMEs often cannot afford top professionals in a particular area or offer a number of fringe benefits such as large companies do. Thus, to discover and retain qualified employees is a persistent dilemma. Penetration to the foreign market is also more complicated because SMEs lack sufficient information about foreign legislation, potential partners or the market and their accessibility to counselling services remains on a lower level. Last but not least, impossibility of using so called returns to sized is also usually mentioned among disadvantages of SMEs.

By contrast, if we would like to summarize advantages of this business type, the most significant one of SMEs would be seen in their flexibility, ability to improvise and adapt promptly to customer's needs - small and medium-sized enterprises can react to changes on the market in a more rapid and way than large corporations. In general, SMEs are characterized by simple organizational structure and a low number of management levels, which enables fast reactions to actual situation on the market and decision making without unnecessary communication noises and intercompany conflicts among employees. The simple organizational structure yields lower expenses on enterprise management and decease of bureaucracy level; also enterprise foundation is not usually as financially demanding as in the case of large companies. Besides, other advantages can be mentioned, such as a friendly atmosphere and ties of almost familial character which often form on workplaces of small firms. In small enterprises, workers are ordinarily in a direct contact with an entrepreneur, which enables easier growth of confidence between employees and an organization; workers' loyalty to their company also often increases. In addition, SMEs more often support new ideas, various changes and innovations of their employees who have therefore better chance of realization than in larger enterprises. Last but not least, it is necessary to mention closer contact with customers among all significant advantages of SMEs.

\section{Small and Medium-Sized Enterprises in the Czech Republic} A position of SMEs has been relatively stable in the last ten years. Small and medium-sized entrepreneurs represent stabilizing element in the Czech Republic especially in terms of employment rate where they constantly keep a share slightly above $60 \%$ of total employment with a modest tendency to grow. Their GDP and export rate is comparable to that of large companies. SMEs' share in performances and produced value added shows long-term 
stability as well, it is above $50 \%$ (see table 1 ). In respect of the SMEs' role in particular sectors of national economy, it is possible to say that small and medium-sized entrepreneurs distinctively predominate in terms of the employment rate and value added in catering, services, commerce and building industry with a share of $80 \%$ and more. In industry and transport, a share of small and medium-sized entrepreneurs is approximately one third of total employment rate and value added. Participation of SMEs in overall investments realized in the Czech Republic is relatively high and it still keeps growing. In 2004, it exceeded $50 \%$ and this trend continued in following years. In terms of a structure of a SMEs sector in the Czech Republic, the most important share is represented by entrepreneurs from particular branches of processing industry, commerce and service. To achieve necessary competitiveness, persisting technological backwardness which affects several business sectors is still compensated with a cheaper labour force and comparatively long real working hours.

\section{Tab. 1: Rate of SMEs in particular macroeconomic indicators (in \%)}

\begin{tabular}{l|c|c|c|c|c|c|c|c|c|c|c} 
Indicator & $\mathbf{1 9 9 9}$ & $\mathbf{2 0 0 0}$ & $\mathbf{2 0 0 1}$ & $\mathbf{2 0 0 2}$ & $\mathbf{2 0 0 3}$ & $\mathbf{2 0 0 4}$ & $\mathbf{2 0 0 5}$ & $\mathbf{2 0 0 6}$ & $\mathbf{2 0 0 7}$ & $\mathbf{2 0 0 8}$ & $\mathbf{2 0 0 9}$ \\
\hline Number of enterprises & 99.80 & 99.71 & 99.81 & 99.85 & 99.81 & 99.84 & 99.85 & 99.84 & 99.84 & 99.83 & 99.83 \\
\hline Number of employees & 58.84 & 59.42 & 59.73 & 61.34 & 61.63 & 61.48 & 61.63 & 61.76 & 61.62 & 61.52 & 62.33 \\
\hline Performances & 53.63 & 51.53 & 51.44 & 52.46 & 52.79 & 52.29 & 52.42 & 52.94 & 51.90 & 51.53 & 53.21 \\
\hline Book value added & 53.17 & 51.93 & 51.33 & 52.98 & 54.46 & 53.02 & 53.68 & 55.12 & 54.01 & 54.57 & 55.87 \\
\hline $\begin{array}{l}\text { Labour expenses } \\
\text { (without OPC) }\end{array}$ & 54.57 & 54.42 & 55.72 & 55.82 & 55.90 & 55.61 & 55.88 & 56.03 & 56.06 & 55.90 & 56.28 \\
\hline Investments & 41.06 & 40.48 & 37.81 & 44.52 & 49.88 & 51.43 & 52.57 & 55.33 & 55.78 & 56.00 & 60.79 \\
\hline Export & 36.54 & 36.15 & 35.74 & 34.16 & 34.0 & 343 & 40.7 & 45.2 & 45.41 & 46.04 & 50.7 \\
\hline Import & 50.74 & 49.43 & 47.12 & 50.33 & 49.8 & 52.5 & 54.7 & 56.3 & 54.45 & 56.01 & 57.4 \\
\hline GDP & 31.54 & 31.17 & 31.63 & 34.59 & 34.86 & 34.69 & 34.44 & 36.86 & 35.76 & 35.17 & 36.22 \\
\hline
\end{tabular}

Source: MPO, 2005

Small and medium-sized enterprises represent a significant part of the Czech economy, which is confirmed by a fact that their share in a total number of active business subjects in 2009 was $99.83 \%$. SMEs considerably contribute to the creation of vacancies; it amounts to $62.33 \%$ in the Czech Republic. Performance development of SMEs in the Czech Republic in years 1999-2009 showed a long-term increasing tendency but in 2009 , it was marked by the global crisis. In 2009, SMEs produced a performance amounting to 3,912,547 million CZK, which corresponds to a decrease of 589,332 million CZK or $13.1 \%$ in comparison with 2008 . In 2009 , year-on-year growth manifested itself only in performances of banking, information and communication sphere. The greatest decrease affected the sector of industry, services and building. In 2009, SMEs' share in overall performances of business sphere reached $53.21 \%$, which shows a 1.85 percentage point decline in comparison with 2008. A book value added development showed an increasing trend until 2008 as well. Its decrease was registered in 2009 when SMEs produced $1,313,886$ million CZK of the book value added which corresponds to a decrease of 78,155 million CZK or $5.61 \%$ in comparison with 2008 . Only sectors of banking and information and communication technologies displayed a year-on-year growth. The largest decrease was observed in spheres of services, commerce and industry. In the Czech Republic, the rate of SMEs' value added on total sum was $55.87 \%$. In 2009, book value added per employee in SMEs showed a decline of $1.96 \%$ in comparison with 2008.

As regards foreign trade development of small and medium-sized enterprises in the Czech Republic, export has manifested a continuous growth in absolute value since 2005. In 2009, 
a year-on-year SMEs' export decreased by 66,250 million CZK, i.e. $5.78 \%$ (see Fig. 1). In 2009, a share of SMEs' export on overall export was $50.73 \%$, which correspond to $4.35 \%$ increase in comparison with 2008. In case of import, a SMEs' share represented $57.36 \%$, i.e. a 1.08 rise in the same period of time. A higher share of SMEs in import is related to a focus of business organizations in this sector which provide importation for large companies as well.

Fig. 1: Foreign market development of SMEs in the Czech Republic in years 1998-2009

Foreign market development of SME in the Czech Republic in years

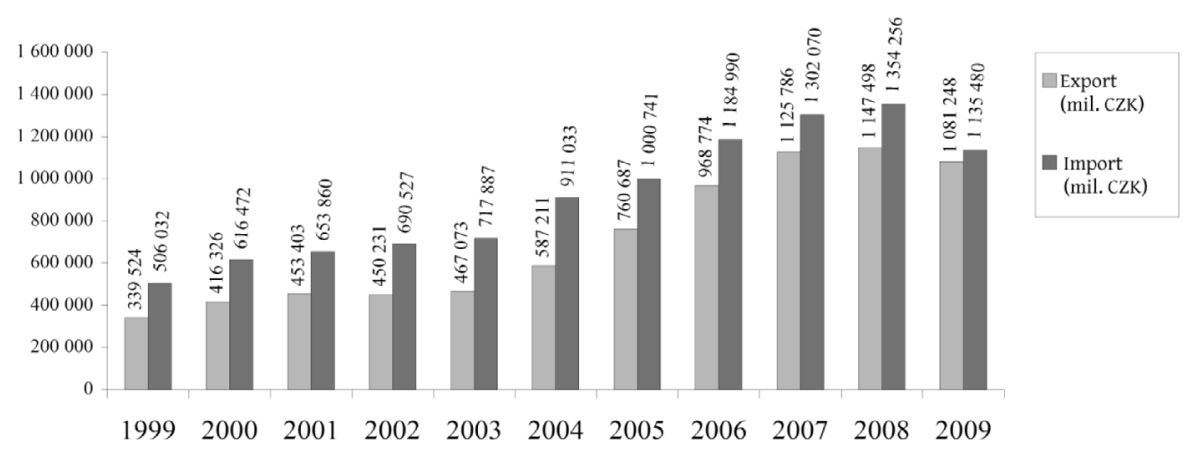

Source: MPO, 2005

Small and medium-sized enterprises (SMEs) represent a significant market sector of the economy. They are a motive force of a business sphere, innovation and competitiveness. They also considerably contribute to the creation of vacancies and GDP. In the economic union of EU, SMEs plays a significant economic and political role. The reason is not only their high number but also the aspect of creating vacancies, social stability and innovation development dynamic. Thus, a great deal of attention has been paid to SMEs evolution and their economic, organizational and legislative support has been accentuated. An advantage of small and middle-sized enterprises lies especially in their ability to react to changes on the market in a rapid and flexible way. On the other hand, they often have to deal with insufficient funds and their access to foreign sources is more complicated than that of large-sized enterprises.

\section{Success Evaluation of Small and Medium-Sized Enterprises}

With regard to how important role small and medium-sized enterprises play in the world economy, many of the Czech and foreign professionals intensively focus on success evaluation methods applicable in the case of SMEs. Even though numerous models of business success concerning SMEs which operate either on a home market or joining the internalization process were presented in Czech and foreign literature, all the evaluation methods have a common factor - identification of SMEs' success key factors which differ from success key factors of large enterprises. These are the business success determinants on which should SMEs concentrate.

There are numerous factors which involve success of small and medium-sized enterprises. [20] established a model for business success of small and medium-sized enterprises. To simplify the model, the authors merged the success factors into three areas which contain a personality of an entrepreneur (among others, it includes personal initiative, willingness to take risks and responsibility, etc.), business operations and management, and an environment in which the business takes place. To become successful, it is indispensable for an enterprise 
to have a definite idea about the way it will proceed, to set targets which it will try to achieve and naturally a strategy how to achieve them.

Another model focused on success evaluation of small and medium-sized enterprises is the model of critical success factors by [32] which was designed for Czech SMEs that have been operating or are going to operate in the conditions of the advanced market economies in the EU. The model is conceived as a group of factors interconnected by relations in the Framework of which they interact. Among the factors belong those of internal environment, namely: strategy, leaders, structure, workers, IS/IT and processes influenced by knowledge, cultural and innovative background that are in interaction with positive, neutral or negative cooperative environment of a specific enterprise. The mutual interaction of these critical success factors differs according to the reciprocal level of particular factors coordination in a desirable or undesirable way. Thus, harmonious factors represent a key precondition for successful operation of small and medium-sized enterprises. According to [32], it holds that functioning of every individual factor cannot be appropriately understood and interpreted without its integration into the context of all other model components. The main aim of the model is to record a comprehensive system characteristics of requirements on SMEs' managerial work.

In the Czech and foreign literature, there are available other models evaluating SMEs' success which take into consideration even SMEs' integration to the internationalization process. Generally, it is possible to define two different approaches to SMEs' evaluation. The first one divides enterprises into exporters and those operating exclusively on the home market. The second approach focuses on export intensity tracing export sales' share of total sales [5], [34].

Dividing the enterprises into exporting and not exporting companies is criticised since it is impossible to consider all the export activities as successful. The indicator of export intensity has its critics as well, e.g. [8] because this approach focuses on export sales' share of total sales while neglecting profit and other export related benefits. It appears to be most suitable to use multidimensional indicators to measure a success of SMEs' international performance. It is necessary to pay attention to export sales' rate and profitability of international activities both absolute and relative. Other success indicators are management satisfaction with international activities and a degree of objective achievement. Related definition by [28] introduces success indicators of SMEs' in foreign markets that focus on intensity of their international activity, total profitability of international activities, successful objective achievement and management satisfaction.

A complex indicator of "overall performance" is a sum of all above mentioned criteria. This system of SMEs classification allows complex evaluation of small and medium-sized enterprises using multidimensional indicators (both subjective and objective). It focuses on export sales rate, international activities profitability (both absolute and relative), and surveys SMEs management satisfaction with international activities as well as ensures that selected objectives was achieved. On the basis of these data, the overall performance of SMEs can be analysed.

\section{Internationalization Process of SMEs}

Since the aforementioned models concerns the element of internationalization process involvement, it is necessary to disambiguate the term internationalization. The internationalization can be described as a "process of increasing involvement of enterprises in international markets" [33]. The concept of internationalization in professional literature differs from author to author. For instance [2] perceives internationalization as a process by which firms both raise their awareness of the direct and indirect influence of international transactions and relationships on their future, and establish and entertain transactions and relationships with entities from other countries. In another definition by [6], internationalization is seen as a process of enterprise involvement in international transactions based on the form and degree of involvement.

Other definitions understand the term internationalization as one of the stages of globalization that can be divided into a stage of internationalization (export and free-market), transnationalization (foreign direct investments) and globalization (widening manufacturing and information infrastructure). 
Business activity of an enterprise can be divided into several phases if perceived as involvement in international environment. All the enterprises start the internationalization process by operating on home market exclusively. The final stage of the process is represented by multinational companies which symbolize the highest maturity level of internationalization. All the other stages of enterprise foreign market involvement find themselves between these two poles. It holds that higher involvement in foreign activities implies a higher risk. There are often several different internationalization stages existing simultaneously, an enterprise can utilize several internationalization stages and methods at once. A new stage can gradually replace the old one without its entire supersession or an enterprise can use different internationalization methods in different countries. An unambiguous definition of the internationalization is not entirely mandatory for an enterprise; it is much more important to find a way how to quantify the degree of involvement in the internationalization process and define the factors affecting success in the internationalization process.

There are three indicators that can be used for measuring the degree of internationalization:

\section{- foreign capital's share of total capital, - foreign sales' share of total sales, \\ - number of employees abroad share of total number of employees.}

An arithmetical average of these indicators is called the transnationality index.

Besides the degree of internationalization, it is useful for an enterprise to analyse the dynamics of the internationalization process. According to [30], dynamics of internationalization depends on five different factors. The degree of exertion while entering foreign markets determines whether the enterprise reacts on foreign signals passively or if it actively looks for opportunities. Control over foreign market operations might be commended to the third-party (salesmen, commission agents, etc.) or an enterprise owns and controls all its foreign activities itself. While considering the way of entering the foreign markets, it is important whether an enterprise solely imports and exports, builds limited production and distribution facilities abroad or utilizes straight investments and strategic alliances. And last but not least, it depends on a number of countries in which the company operates and similarity of target foreign markets.

In connection with the polemics concerning a degree of enterprise internationalization, it is possible to discuss a degree of enterprise globalization. Although there is no consensual definition of these terms, [24] perceive an "internationalization degree" as a degree directly proportional to export rate and "globalization degree" as a degree directly proportional to the number of continents at which is an enterprise exporting.

The success of enterprises in the international process is affected by the number of factors and there are many of authors focussing on their identification. For example [13] claim that the enterprise internationalization process should respect following five principles to be internationally successful:

1. An enterprise should have well-developed and clearly defined mission reflecting the commitment to international business.

2. An enterprise should be able to recognise and adapt quickly to customer preferences, international market opportunities and take advantage of a products reflecting competitive advantage of an enterprise.

3. An enterprise should understand the behaviour of customers from different cultures and evaluate the nature of the differences.

4. An enterprise should innovate and maintain the quality of the product to succeed in competition on both home and foreign market.

5. An enterprise should perform effective market surveys.

\section{Theories Concerning the Process of Internationalization}

In connection with discussions concerning the internationalization process of enterprises, there is a need to determine why there are some enterprises that get involved in the international trade gradually, whereas others are enter foreign market faster or even are "born" for the global market. Currently, there is a large number of theories about these issues and many authors concerned with them, such as [12]. They have based their work on two different theories about internationalization so-called Uppsala model [17] and the 
Innovation-Related Model [7]. The most famous and the oldest Uppsala models illustrate two ways of the internationalization process of an enterprise. According to the first model, the number of operations on foreign market evolves gradually, so the enterprise increases its engagement in foreign market little by little. In 1975, 4 phases of that process were described by [19]:

1. stage: no regular export activities,

2. stage: export utilizing foreign agents,

3. stage: establishing a subsidiary company abroad focused on sales,

4. stage: foreign production/foreign production unit establishing.

According to the second model, an enterprise continually tends to enter the foreign markets with higher "psychic distance", which includes markets that are unknown, different, culturally distant and in most of cases markets which are geographically more distant. The "psychic distance" is defined as a number of factors preventing information to flow from market to market [17]. Consequently, fewer enterprises are able to understand these markets and regard them as potentially dangerous. This is the reason why enterprises enter the known markets first, since they are able to recognize the opportunity minimizing probability of failure. The best way to minimize perceived uncertainty and recognize an opportunity is the empirical evidence, which means knowledge based on experience. Enterprises gain knowledge mainly thanks to their experience with a particular market. This is the reason why the enterprises are getting involved in foreign markets one step after another. Enterprises usually start to invest on one or few markets in neighbour countries.

Uppsala model is generally based on a four core concept taking into account four key factors which include a market commitment, market knowledge, current activities and commitment decisions. These four factors can be divided into two groups of factors concerning either enterprise state aspects or aspects influencing changes in an enterprise. Among the enterprise state aspects belong market commitment (it is necessary to specify which sources participate in foreign markets) and market knowledge (what information does a company have about foreign markets). The factors involving change aspects are current activities and commitment decisions. All of the four core concept groups of factors are interlinked and affect each other. However, the Uppsala model is often criticised nowadays and its critics point out that it is not applicable on large multinational enterprises, enterprises having rich experience and hightech enterprises. [4] claim that the crucial problem of this model is the emphasis which was put on organisational learning as a motive power for internationalization and the fact it does not take into account an effect of empirical knowledge on organizational behaviour. Another antagonist of the model, [26] declares that current development tendencies absolutely disprove the basic assumptions of Uppsala model. He supports the thesis by a statement that the world has moved towards homogenisation of a trade community especially in virtue of the communication and transport development, which allowed global markets to be created. The second argument is that the enterprises' access to information about markets became easier. The third argument describes an increasing number of enterprises operating on global markets that perceive the world as a homogeneous market with no boundaries.

Except the Uppsala model, there is "the theory of learning enterprise" frequently mentioned in the literature among theories concerning the internationalization process. According to this theory, enterprises start unfamiliar with certain markets and gradually gain knowledge, reduce their aversion towards risk and get involved in the internationalization process more often. Another theory [16] perceives the process of internationalization similarly, stating that the level of internationalization of the market affects enterprises' internationalization process, so that enterprises operating on highly internationalized markets can skip several initial stages.

In conjunction with aforementioned question why some enterprises get involved in an international trade gradually whereas others enter foreign market faster or are even "born" for a global market, several authors (e.g. [27], [22]) prove the existence of a specific type of exporters, whom they call "Born Globals" (hereinafter BGs). Those are the enterprises focusing on international markets or even on global market immediately after their foundation omitting all the development stages. Some 
enterprises, usually BGs, often start their activities on several markets at once and their production is tailored for an international (or global) market. There is no consensus in a professional literature in BGs definition. According to several sources (e.g. [23] or [14]), BGs are enterprises with an export rate higher than $25 \%$ in 3 years after their foundation. However, this definition might appear not accurate and vague, because for example if a small Norwegian company exports $30 \%$ of its products to Sweden and Denmark, it could be hardly considered global. Therefore it is necessary to define more precisely a kind of market, number of different countries and amount of overall production an enterprise should export to be called "Born Global". Nowadays, most of the small and medium-sized enterprises have the export rate exceeding $25 \%$. The aforementioned authors [24] defined BGs as enterprises whose export reaches $50 \%$ within 3 years after their foundation. They also introduce a new category of enterprises "True Born Global", which corresponds to a company that exports more than $50 \%$ of its production to several continents in less than three years.

According to [6], the theories concerning internationalization process of enterprises can be divided into four groups of understanding and explanation theories of enterprise's internationalization behaviour:

1. The Transaction Costs Analysis was first used by [1]. They verified hypotheses if a way of entering a foreign market is dependent on a supervision level and a market entering expenses.

2. The Eclectic Paradigm assumes that factors included in the model affect a rational decision-making process. [9], [15]

3. The Theory of Stages covers both Uppsala model and the I-Model.

4. The Network Theory [18], [16] partially corresponds to the eclectic paradigm because it exclusively concerns market factors. This theory is based on experience that the relationships among enterprises are established and developed by mutual influence. Thanks to these relationships, enterprises build mutual trust and knowledge that leads to stronger involvement.

Some authors, for example [10] or [1], consider the first two theories suitable for studying the internationalization process of large multinational enterprises and for enterprises in late stages of internationalization process, but not for small and medium-sized enterprises. The group of so-called stage models (that includes Uppsala) has its both protagonists and antagonists that tried to verify its suitability for small and medium-sized enterprises in practice. Most authors (for instance [3] or [12]) consider the stage model applicable for studying the internationalization behaviour of SMEs.

However the internationalization process of SMEs has drawn plenty of attention recently, there is still not enough empirical knowledge to utilize for evaluating internationalization process of SMEs.

\section{Specific Aspects of Internationalization of Small and Medium-Sized Enterprises}

Different possibilities of large, medium and small sized enterprises are often discussed in professional literature in connection with the internationalization process. An advantage of small sized enterprises lies especially in their ability to adapt easily to market changes; however they often have to contend with the capital deficit and their access to foreign enterprise resources is more difficult in comparison with large sized enterprises. The process of globalization leads to massive internationalization of the world economy encouraging international economic relationship development and mutual dependence of involved countries. Small and medium-sized enterprises are forced to deal with the question of internationalization because a competition from abroad is growing stronger and the internationalization is one of the options how to face it.

For this reason, SMEs have been more frequently analysed in an effort to identify key factors, which involve their ability to succeed in international activities. Those factors could positively influence other SMEs in their plans to participate in the foreign trade. However, not all the enterprises have equal conditions for entering the foreign market field. In some business spheres, the export of SMEs is supported, which is considerably helpful, mainly in case of enterprises with insufficient funds. Some of the other spheres facilitate access to the foreign market because of their sort of production.

There are several strategies for SMEs to achieve internationalization. One of the 
possibilities is to focus on a product type which an enterprise produces since it is may be the key factor for the internationalization process. A growing competition on the global market leads to shortening of the product life cycle and especially to higher intensity of innovation. The shorter life cycle emphasizes the search for new opportunities, their timing and fast utilization. It also implies shorter time for development investment to return. These arguments under score a need for enterprises with a small domestic market to achieve a foreign market to distribute the expenses (for example expenses on research and development costs).

Another key factor for success on the international market is experience of the company founders (managers). International experience is usually defined as a understanding and realistic perception of foreign operations, risks and returns in foreign markets. In conjunction with growing experience of an enterprise, an aversion to a risk connected with investing of a larger amount of capital decreases. According to [11], there are several parameters of enterprise international experience.

1. geographic coverage defining the scope of firm's experience (the number of countries I which a company is active),

2. length of experience (number of years a firm has been active on the international arena).

According to that sized, it may appear that the BGs are considered unpractised since the "length of experience" of enterprises operating on foreign markets is very low. However, the empiric studies (e.g. [27], [29], [10]) illustrated that the important employees of BGs very often gained rich experience in international business activities earlier in their carriers, which minimizes the handicap resulting from the short length of an enterprise's existence. There are other studies suggesting the possibility of cooperation with foreign partners. This kind of partnership can provide certain important resources such as specific skills or capital. The resources are especially important when a young enterprise with insufficient funds tries to increase foreign sales. Collaboration allows an enterprise to enter the market faster as was empirically demonstrated by [10]. Various environments can cause significant differences in the speed of transition from traditional international companies or BGs to globally operating enterprises. If the conditions change quickly enough so that we can talk about socalled growing globalization, the process of internationalization will probably accelerate too, as was proved by [22]. Another important fact to realize is that a rival position in a business sphere in one country affects the position of a company in another and vice versa. In the age of growing globalization, it is easier to enter a foreign market than ever before, but the competition is stronger as well.

As we can see, there is a huge set of theories and methodologies concerning the internationalization process of an enterprise, but just a handful of them take specific aspects of SMEs into account.

However, to find a study concerning the process of internationalization of small and medium-sized enterprises in Czech Republic is rather problematic. In 2006, inspired by the Finnish researchers [21], the author of the paper decided to initiate an extensive survey among Czech SMEs with her colleagues and tried to verify various internationalization models in practice. One of the outputs of the survey is the identification of key factors which affect the internationalization process of Czech SMEs. There are interesting findings that arose from the Finnish research, for instance both successful and unsuccessful international enterprises are focused on customers. Moreover, the managers of Finnish enterprises are convinced that competitive advantage is established by satisfied customers.

Inspired by the Finnish colleges, there were performed several researches among Czech SMEs involved in internationalization process in different business spheres (civil engineering, mechanical engineering, viticulture). According to the survey, the key factors of success are almost the same, even though conditions of SMEs participation in foreign markets operations differ across the business spheres. The successful internationalization process adoption survey was performed on a food-processing industry as well.

\section{Success Evaluation of SMEs Operating in Food-Processing Industry}

As stated above, [28] have defined SMEs success indicators on foreign market taking into account the SMEs international activity 
intensity, overall profitability of international activities, relative profitability of international activities, defined target achievement and management satisfaction. They also created a complex indicator called "overall performance" as a summary of all mentioned criteria. Since this systems of SMEs classification allow complex evaluation of small and medium-sized enterprises in using multidimensional indicators (both subjective and objective), it was used for evaluation of 96 small and medium-sized enterprises operating in the food-processing industry in a whole country. 697 SMEs operating business sphere were questioned at the turn of the year 2010 and 2011 and 96 of them were obtained because properly filled in on-line questionnaires and operating internationally.

Among the questioned companies, there were $62.5 \%$ limited liability companies, $12.5 \%$ stock companies and the same portion of cooperatives and self-employed individuals. Of all the SMEs, $25 \%$ entered foreign market less than one year after founding, $12.5 \%$ within first two years and the same portion from 3 to 4 years. Within the 4 years after founding, $50 \%$ of asked companies entered the foreign market. As the most common way of entering foreign market, indirect development (using commissioned agent) was chosen in $62.5 \%$ of cases. Remaining $37.5 \%$ respondents chose direct import. Majority of questioned $(75 \%)$ delivers the product to foreign agents (warehouse, etc.) and the rest $(25 \%)$ delivers to the end customer. Language skills are indispensable for SMEs internationalization of activities. As it was confirmed by the survey, $50 \%$ of respondents considered language skills of key employees very good, $37.5 \%$ regarded it as average and $12.5 \%$ described it as low. It is necessary for the internationalization process to communicate with foreign partners. According to $50 \%$ of respondents, the management communicate with foreign partners several times a week, $25 \%$ of respondents communicate on everyday basis. By communication are meant letters, email, phone calls, video-conferences and personal meetings. Most of the respondents $(62.5 \%)$ declared that before expansion, the key employees had limited experience and $37.5 \%$ had no experience with foreign markets at all. SMEs usually target their activities to a certain market segment $(75 \%)$. Performing the internationalization processes, $37.5 \%$ of respondents focus on a differentiation strategy and $25 \%$ concentrate on a price strategy. As an objective of the export activities, $50 \%$ of the enterprises established the maximization of sales, $15.5 \%$ the maximization of income and the same portion achieving certain foreign market share.

All aforementioned factors were examined to identify their influence on internationalization process.

All the companies were divided into two groups (successful and unsuccessful) in foreign activities based on the evaluation of overall performance. Of all the 96 respondents, there were $50 \%$ considered successful and $50 \%$ unsuccessful. No SMEs participating in the survey could be evaluated as very successful. After evaluation of respondent's overall performance, the dependency between overall performance and individual factors was analysed by using a PC programme STATISTICA 9.0. The result of this analysis was an identification of the factors affecting the SMEs success on foreign markets. The most interesting factors are stated in Tab. 2 together with Pearson's chi-squared distribution, contingency coefficient and Cramer's $\mathrm{V}$ coefficient. For dependency verification $\chi^{2}$ test was used (significance level $\alpha=0.01$ ).

\section{Conclusion}

An actual and often discussed topic of SMEs success led to survey initiation, which main aim was to identify the factors influencing s success of small and medium-sized enterprises on foreign markets with special attention concentrated on subjects operating in the foodprocessing industry. This article describes the methodology and the results of the project. An important characteristic of SMEs related to their operation on foreign markets was determined by studying professional resources. Other necessary information was obtained from Czech SMEs active on foreign markets. Based on the data, all the enterprises were evaluated by using defined success indicators and ranked as "successful" or "unsuccessful" concerning to their international activities. No SMEs participating in the survey could be evaluated as very successful. After that, a dependency analysis between success indicators and the categories was performed. This analysis 
Tab. 2: Values of overall performance dependence on SMEs factors

\begin{tabular}{|c|c|c|}
\hline Factors & Coefficients & Overall performance \\
\hline \multirow[t]{4}{*}{ Legal form of business } & Person's chi-square distribution & 57.60 \\
\hline & $p$-value & 0.00 \\
\hline & Contingency coefficient & 0.61 \\
\hline & Cramer's V coefficient & 0.77 \\
\hline \multirow{4}{*}{$\begin{array}{l}\text { Period from an initiation of business to an expansion } \\
\text { abroad }\end{array}$} & Person's chi-square distribution & 72.00 \\
\hline & $p$-value & 0.00 \\
\hline & Contingency coefficient & 0.65 \\
\hline & Cramer's V coefficient & 0.87 \\
\hline \multirow{4}{*}{$\begin{array}{l}\text { Language knowledge of key employees before } \\
\text { an entrance to a foreign market }\end{array}$} & Person's chi-square distribution & 28.00 \\
\hline & $p$-value & 0.00 \\
\hline & Contingency coefficient & 0.48 \\
\hline & Cramer's V coefficient & 0.54 \\
\hline \multirow{4}{*}{$\begin{array}{l}\text { Language knowledge of key employees before } \\
\text { an expansion with operating on foreign markets }\end{array}$} & Person's chi-square distribution & 96.00 \\
\hline & $p$-value & 0.00 \\
\hline & Contingency coefficient & 0.71 \\
\hline & Cramer's V coefficient & 0.89 \\
\hline \multirow[t]{4}{*}{ Targets of export activities } & Person's chi-square distribution & 48.00 \\
\hline & $p$-value & 0.00 \\
\hline & Contingency coefficient & 0.58 \\
\hline & Cramer's V coefficient & 0.71 \\
\hline \multirow[t]{4}{*}{ Sector of foreign market which an enterprise specializes in } & Person's chi-square distribution & 24.00 \\
\hline & $p$-value & 0.00 \\
\hline & Contingency coefficient & 0.45 \\
\hline & Cramer's V coefficient & 0.50 \\
\hline \multirow[t]{4}{*}{ Strategy pursued in foreign countries } & Person's chi-square distribution & 16.00 \\
\hline & $p$-value & 0.00 \\
\hline & Contingency coefficient & 0.38 \\
\hline & Cramer's V coefficient & 0.41 \\
\hline
\end{tabular}

identified the factors affecting success of SMEs on foreign markets. These factors are: legal form of business $\left(\chi^{2}=\mathbf{5 7 . 0 0}, \mathrm{p}\right.$-value $=\mathbf{0 . 0 0}$, contingency coefficient $=0.61$, Cramer's V coefficient $\mathbf{~} \mathbf{0 . 7 7}$ ), amount of time between opening the business and foreign market expansion $\left(\chi^{2}=\mathbf{7 2 . 0 0}\right.$, p-value $=\mathbf{0 . 0 0}$, contingency coefficient $=0.66$, Cramer's V coefficient $=\mathbf{0 . 8 7}$ ), language skills of key employees before entering foreign market $\left(\chi^{2}=28.00, p\right.$-value $=0.00$, contingency coefficient $=\mathbf{0 . 4 8}$, Cramer's V coefficient $=$ $=0.54$ ) and employee experience with foreign market expansion $\left(\chi^{2}=\mathbf{9 6 . 0 0}\right.$, p-value $\mathbf{= 0 . 0 0}$, contingency coefficient $=0.71$, Cramer's $V$ coefficient $\mathbf{0} \mathbf{0 . 8 9}$ ). Another factors affecting success on foreign markets are objectives

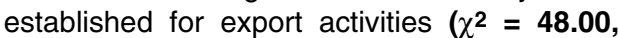
$\mathrm{p}$-value $\mathbf{=} \mathbf{0 . 0 0}$, contingency coefficient $\boldsymbol{=} \mathbf{0 . 5 8}$, Cramer's V coefficient $=\mathbf{0 . 7 1}$ ), market segment

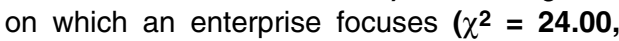
$\mathrm{p}$-value $\mathbf{0} \mathbf{0 . 0 0}$, contingency coefficient $\mathbf{0} \mathbf{0 . 4 5}$, 
Cramer's V coefficient $=0.50$ ) and the strategy with an enterprise follows abroad $\left(\chi^{2}=16.00, p\right.$-value $=0.00$, contingency coefficient $=0.38$, Cramer's V coefficient $=0.41$ ).

The paper was elaborated in connection with solution of the research plan of the Faculty of Business and Economics, Mendel University in Brno, No. MSM 6215648904.

\section{References}

[1] ANDERSEN, O. On the Internationalization Process of Firms: A Critical Analysis. Journal of International Business Studies. 1993, Vol. 24, Iss. 2, pp. 209-231. ISSN 0047-2506.

[2] BEAMISH, P.W. The Internationalization Process for Smaller Ontario Firms: A Research Agenda. In RUGMAN, A. (Ed.). Research in Global Business Management. Vol. 1. Greenwich, CO, JAI Press, 1990. pp. 77-92.

[3] BILKEY, W.J., TESAR, G. The Export Behavior of Smaller Wisconsin Manufacturing Firms. Journal of International Business Studies. 1997, Vol. 8, Iss. 1, pp. 93-98. ISSN 0047-2506.

[4] BJÖRKMAN, I., FORSGREN, M. Nordic International Business Research. International Studies of Management \& Organization. 2000, Vol. 30, Iss. 1, pp. 6-24. ISSN 0020-8825.

[5] BONACCORSI, A. On the Relationship between Firm Size and Export Intensity. Journal of International Business Studies. 1992, Vol. 23, Iss. 4, pp. 605-635. ISSN 0047-2506.

[6] BŘEČKOVÁ, P. Expanze českých malých a středních firem na zahraniční trhy [online]. Brno, 2003 [cit. 2006-06-13]. 6 p. (PDF). Dostupné z: http://www.fce.vutbr.cz/veda/dk2003texty/pdf/ 5-1/np/breckova.pdf.

[7] CAVUSGIL, S.T. On the Internationalization Process of Firms. European Research. 1980, Vol. 8, Iss. 6, pp. 273-281.

[8] DHANARAJ, C., BEAMISH, P.W. A resourceBased Approach to the Study of Export Performance. Journal of Small Business Management. 2003, Vol. 41, Iss. 3, pp. 242-261. ISSN 1540-627X. [9] DUNNING, J.H. The eclectic paradigm of international production: A restatement and some possible extensions. Journal of international Business Studies. 1988, Vol. 19, Iss. 1, pp. 1-31. ISSN 0047-2506.

[10] ELLIS, P. Social ties and foreign market entry. Journal of International Business Studies. 2000, Vol. 31, Iss. 3, pp. 443-469. ISSN 0047-2506.
[11] ERAMILLI, M.K. The Experience factor in foreign market entry behaviour of service firms. Journal of International Business Studies. 1991, Vol. 22, Iss. 3, pp. 479-501. ISSN 0047-2506.

[12] GANKEMA, H.G.J., SNUIF, H.R., ZWART, P.S. The Internationalization Process of Small and Medium-Sized Enterprises: An Evaluation of Stage Theory. Journal of Small Business Management. 2000, Vol. 38, No. 4, pp. 15-27. ISSN 1540-627X.

[13] HARRISON, A.L., DALKIRAN, E., ELSEY, E. International business: global competition from a European perspective. Oxford: Oxford University Press, 2000. 491 p. ISBN 0-19-878213-6.

[14] HARVESTON, P.D., KEDIA, B.L., DAVIS, P.S. Internationalization of born global and gradual globalizing firms: The impact of the manager. Advances in Competitive Research. 2000, Vol. 8, Iss. 1, pp. 92-99. ISSN 1077-0097.

[15] HILL, C.W., HWANG, P., KIM, W.C. An Eclectic Theory of Choice of International Entry Mode. Strategic Management Journal. 1990, Vol. 11, Iss. 2, pp. 117-128. ISSN 1097-0266.

[16] JOHANSON, J., MATTSSON, L.G. Internationalization in Industrial Systems - A Network Approach. In HOOD, N., VAHLNE, J. (Eds.). Strategies in Global Competition. New York: Croom Helm, 1988. pp. 287-314. ISBN 978-0-7099-3796-2.

[17] JOHANSON, J., VAHLNE, J.E. The Internationalization Process of the Firm A Model of Knowledge Development and Increasing Foreign Market Commitments. Journal of International Business Studies. 1977, Vol. 8, Iss. 1, pp. 23-32. ISSN 0047-2506.

[18] JOHANSON, J., VAHLNE, J.E. The mechanism of internationalisation. International Marketing Review. 1990, Vol. 7, Iss. 4, pp. 11-24. ISSN 0265-1335.

[19] JOHANSON, J., WIEDERSHEIM-PAUL, F. The internationalisation of the firm - Four Swedish cases. Journal of Management Studies. 1975, Vol. 12, Iss. 3, pp. 305-322. ISSN 1467-6486.

[20] KISLINGEROVÁ, E., NOVÝ, I. Chování podniku $v$ globalizujícím se prostředí. Praha: C.H. Beck, 2005. 464 s. ISBN 80-7179-847-9.

[21] KJELLMAN, A., SUNDNÄS, A., RAMSTRÖM, J., ELO, M. Internationalisation of small firms. 1. vyd. Vřasa: Keab-Paper Ltd, 2004. 167 s. ISBN 952-91-6726-1.

[22] KNIGHT, G.A., CAVUSGIL, S.T. The born global firm: A challenge to traditional internationalization theory. In CAVUSGIL, S.T., MADSEN, T. (Eds.). Advances in international marketing. 
Greenwich (CT): JAI Press, 1996. pp. 11-26. ISSN 1474-7979.

[23] KNIGHT, G.A. Emerging paradigm for international marketing: The born global firm. East Lansing (MI), 1997. Doctoral dissertation. Michigan State University.

[24] LUOSTARINEN, R, GABRIELSSON, M. Born Finnish perspective of international entrepreneurship. In DANA, L.-P. (Ed.). Handbook of Research on International Enterpreneurship. Cheltenham (UK) and Northampton (MA): Edward Elgar, 2004. pp. 383-403. ISBN 184376069X.

[25] Ministerstvo průmyslu a obchodu [online]. Praha: Ministerstvo průmyslu a obchodu, c2005 [cit. 2011-10-10]. Dostupné z: http://www.mpo.cz/. [26] NORDSTRÖM, K.A. The Internationalization Process of the Firm: Searching for New Patterns and Explanations. Stockholm, 1991. Doktorafhandling. Stockholm School of Economics.

[27] OVIATT, B.M., MCDOUGALL, P.P. Toward a Theory of International New Ventures. Journal of International Business Studies. 1994, Vol. 25, Iss. 1, pp. 45-64. ISSN 0047-2506.

[28] PEPRNÝ, A., KUBÍČKOVÁ, L., ROVNÝ, P. Metoda hodnocení mezinárodní úspěšnosti malých a středních podniků. Acta Universitatis agriculturae et silviculturae Mendelianae Brunensis. 2010, Iss. 3, pp. 183-189. ISSN 1211-8516.

[29] REUBER, A.R., FISCHER, E. The influence of the management team's international experience of the internationalization of SMEs. Journal of International Business Studies. 1997, Vol. 28, Iss. 4, pp. 807-825. ISSN 0047-2506.
[30] ŠTRACH, P. Mezinárodní management. 1. vyd. Praha: Grada, 2009. 167 p. ISBN 978-80-247-2987-9.

[31] VEBER, J., et al. Podnikání malé a střední firmy. 2. vyd. Praha: Grada, 2005. 311 p. ISBN 978-80-247-2409-6.

[32] VODÁČEK, L., VODÁČKOVÁ, O. Malé a střední podniky: konkurence a aliance $v$ Evropské unii. 1. vyd. Praha: Management Press, 2004. 192 p. ISBN 80-7261-099-6.

[33] WELCH, L.S., LUOSTARINEN, R.K. Internationalization: Evolution of a Concept. Journal of General Management. 1988, Vol. 14, Iss. 2, pp. 36-64. ISSN 0306-3070.

[34] WOLFF, J.A., PETT, T.L. Internationalization of Small Firms: An Examination of Export Competitive Patterns, Firms Size, and Export Performance. Journal of Small Business Management. 2000, Vol. 38, Iss. 2, pp. 34-47. ISSN 1540-627X.

doc. Ing. Lea Kubíčková, Ph.D. Mendel University in Brno

Faculty of Business and Economics Department of Marketing and Trade lea.kubickova@mendelu.cz

Ing. Lenka Procházková Mendel University in Brno Faculty of Business and Economics Department of Marketing and Trade lenka.prochazkova@mendelu.cz 


\section{SUCCESS EVALUATION OF SMALL AND MEDIUM-SIZED ENTERPRISES IN TERMS OF THEIR PARTICIPATION IN THE INTERNATIONALIZATION PROCESS \\ Lea Kubíčková, Lenka Procházková}

In context of discussions about the Czech foreign trade development, questions of the Czech enterprises' ability to participate in the internationalization process are often considered. The main aim of this article is to present various points of view on the globalization and enterprise internationalization process with a special accent on the analysis of the specifics in the internationalization process of small- and medium-sized enterprises (SMEs). Those enterprises represent a significant part of the Czech economy because they considerably contribute to the creation of vacancies and GDP; they are a source of innovation and technological progress and the factors of their successful functioning in foreign trades differ from the large-sized enterprises. For this reason, SME shave been more frequently analysed in an effort to identify key factors, which involve their ability to succeed in international activities. Those factors could positively influence other SMEs in their plans to participate in the foreign trade. However, not all the enterprises have equal conditions for entering the foreign market field. In some business spheres, the export of SMEs is supported, which is considerably helpful, mainly in case of enterprises with insufficient funds. Some of the other spheres facilitate access to the foreign market because of their sort of production. Besides analysing the internationalization process of SMEs, this article is also focused on identification of both key factors of success and risk factors of the process. Determinants of SMEs success in the foreign market were examined using several extensive researches among Czech small and medium-sized enterprises of various business spheres. Results of the research have produced interesting information. It was discovered that all SMEs, although they operate in different business spheres, share similar problems concerning the internationalization process. Key factors, which determine success of Czech small and mediumsized enterprises in the internationalization process, are analogous in spite of diverse business spheres, but nevertheless every particular branch has a strong effect on an opportunity and willingness of SMEs to participate in the internationalization process.

Key Words: SMEs, internationalization, success, key factors, success evaluation.

JEL Classification: M160.

DOI: 10.15240/tul/001/2014-2-010 